\title{
FUTURE SCOPE OF SPORT FISHERIES DEVELOPMENT IN INDIA: A REVIEW
}

\author{
A. MANDAL, S. K. DAS ${ }^{1 *}$, B. BISWAS ${ }^{1}$ AND S. O. KAIRNAR \\ Department of Aquaculture \\ College of Fisheries, GADVASU \\ Ludhiana, Punjab, India
}

\begin{abstract}
Sport fishing is one of the most adventurous activities throughout the world. Most of the developed and developing countries have the modern tools and techniques for catching the fish. In the developing country like in India, there is a huge gap on information, scientific knowledge about sport fish as because the sport fishing activities is region and species specific. Though few states in India follow the Government rules and regulation but there is a lack of awareness about sport fishing activities to conserve the threatened and going to endanger fish species. Also the activity will help to mitigate unemployment problem through income generation; simultaneously catering ecotourism avenues. Moreover Government interference is also necessary for sustainable development and management of sport fisheries activity in India.
\end{abstract}

Key words: Conservation, Employment opportunity, Rules and Regulation, Sport fishing, Sustainable development

Recreational fishing, also called sport fishing, is fishing for pleasure or competition. It can be contrasted with commercial fishing, which is fishing for profit, or subsistence fishing, which is fishing for survival. Recreational fishing can be defined as fishing of aquatic animals (mainly fish) that do not constitute the individual's primary resource to meet basic nutritional needs and are not generally sold or otherwise traded on export, domestic or black markets (FAO, 2012). The most common form of recreational fishing is done with a rod, reel, line, hooks and any one of a wide range of baits. Other devices commonly referred to as terminal tackle are also used to affect or complement the presentation of the bait to the targeted fish. Some examples of terminal tackle include weights, floats and swivels. Lures are frequently used in place of bait. Some hobbyists make handmade tackle

*Corresponding Author

${ }^{1}$ Department of Aquaculture, Faculty of Fishery Sciences, WBUAFS, Kolkata, West Bengal 
themselves, including plastic lures and artificial flies. The practice of catching or attempting to catch fish with a hook is known as angling. Big-game fishing is conducted from boats to catch large openwater species such as tuna, shark and marlin. Noodling, an art of capturing mainly large bodied catfish with bare hand and trout tickling are also recreational activities.

Sehgal (1987) defined sport or game fish as the fish caught or angled on rod and line putting up some fight and not thrown back in disgust by the angler or sportsman. In sport fishing, both the choices of gear and the target species for their fighting qualities contribute to the sport of the activity, as the fish is played by the angler until landed or lost (IGFA, 2016). A classification divides sport fishes into small and big ones depending upon the weight of the catch; $50 \mathrm{~kg}$ being the dividing point in between. As a result, mahseers, trouts and snow-trouts belong to the former category whereas, large mahseers, goonch catfish (Bagarius sp.) etc. comes under the next. Depending upon the methods used, there are again a number of nomenclature viz. fly-fishing, still-fishing, plug-casting, surf-casting, trolling, launch fishing, shore fishing spinning etc.

The vast fishery resources of India in the Himalayan and peninsular region in which indigenous mahseer, snow trout, exotic trout and common carp are commercially important (Singh et al., 2014) and also wide climatic diversity of the cold water sector harbour plentiful gene pool are conducive to conservation and growing interest of people in fish farming, ornamental fish keeping and eco-tourism including angling (Singh, 2015).

\section{Rules and Regulations of game fishing}

Fishing in general and sport fishing in particular is not a new venture especially in India as it is referred in the Ramayana and Mahabharata periods. Regulatory measures primarily intended towards conservation of fishes dates back to 300 B.C. during the Maurya Dynasty when there was prohibition on fishing including angling extended from full moon day of Ashar month (mid June) to full moon day of Paush month (mid December) to ensure breeding and protecting the juveniles. Further back, during the reign of King Asoka (269-232 BC), fishing was prevented during July and November because fish breeding occurred during these months.

In sport fishing, both the choices of gear and the target species for their fighting qualities contribute to the sport of the activity, as the fish is played by the angler until landed or lost (IGFA, 2016). Sport fishing generally adheres to a particular set of rules and regulations set by governing bodies such as the International Game Fish Association (IGFA) (Whitelaw, 2013). Given the IGFA's recent inclusion of lagoon, estuarine and freshwater species as game fish (IGFA, 2016); this definition is extended beyond the blue water species usually referred to as game fish in the 
Pacific (IGFA, 2016; Whitelaw, 2003). The most relevant points of the regulation include (i) fishing methods must minimize fish stress and (ii) catch mortality by applying catch-and-release. Also, the tourism venture must contribute to biodiversity conservation and poverty alleviation through the provision of alternative livelihoods and increased income. Therefore, the enhancement of the value of living fish and their supporting habitat to local communities is protected (Holland et al., 2009; Everard and Kataria, 2011).

Although ecotourism emerged as a potential facet for added household income, complete dependence on this sector should be avoided because it is highly sensitive to global financial shocks (Bohensky et al., 2011; Cinner and Orjan, 2010). Instead, to buffer against periods of adverse market conditions a diversity of household livelihood strategies should be encouraged to allow switching to activities unaffected by market shocks (Allison and Ellis, 2001; Pomeroy et al., 2006). Sport fishing projects should encourage other livelihood strategies and options to minimize risk. The introduction of new fishing technologies and practices used for sport fishing could also be adopted by local fishers for other species, increasing fishing success and hence pressure on fish stocks.

\section{Benefits of recreational fishing}

Recreational fishing particularly angling has been recognized by so many medical authorities in the West as a healthy pursuit for long. It has been emerged as a means of outdoor recreation and became popularized as go-fishing during vacations in the occident resulting in tourism ventures. Since trout and mahseer fishing satisfies diverse tastes and pursuits it has become a source of recreation of the tourists attracted to the hills of northern and southern uplands of India (Shegal, 1987). Both social and economic benefits associated with recreational angling worldwide have been recognized (Arlinghaus and Cooke, 2009), and these benefits may be substantial in developing countries (Pinder and Raghavan, 2013; Bower et al., 2014). However, information regarding issues and opportunities for anger associations and participants are extremely meager as the focus of national survey is very poor for the anglers as well as the stakeholders. Recreational angling in India started in British Empire when worldwide anglers visited with their angling skills (Everard and Kataria, 2011).

Though recreational fishing has created income for regional and national economies (Everard and Kataria, 2011), its negative impact have been noticed on biodiversity and ecosystems (Lewin et al., 2006) regarding issue like conservation of threatened and endangered species (Cowx et al., 2010). Therefore, recreational fisheries should be conscious about speciesspecific and better management process (Gupta et al., 2015b). Regrettably, due to poor policy regarding recreational fishing in India (Pinder and Raghavan, 2013) there 
is enough scope for development of better management practices of this emerging sector of fishery activity (Gupta et al., 2015a). Catch-and-release angling has the potential to provide socio-economic benefits to local stakeholders (Pereira et al., 2008; Barnett et al., 2015), generate income for national economies (Suski and Cooke, 2007; Cowx et al., 2010; Danylchuk and Cooke, 2011; Everard and Kataria, 2011) and facilitate both species and ecosystem conservation (Arlinghaus, 2006; Granek et al., 2008; Pinder and Raghavan, 2013).

\section{Genesis of sport fisheries in India}

The history of angling is as old as the world and the earliest known references of fishing dates back to the ancient world. Among the Greeks, great philosophers like Aristotle and Plato referred to the sport of angling, while historian Plutarch offered advice on fishing lines. From Greece and Rome to the ancient civilizations of India and Egypt, fishing played an important role and amalgamated with the creed and culture of the society. The early evolution of fishing as recreation is not lucid in the history of sport fisheries. It is possible that antecedents of recreational fly fishing arrived in England with the Norman conquest of 1066 (McCully, 2000). Although the point in history where fishing could first be said to be recreational is not clear, it became conspicuous with the publication of 'The Compleat Angler' by Izaak Walton in 1653. The book is one of the earliest works that describes fishing's value as a recreational pastime. It is historically ambiguous when exactly recreational fishing began. Fishing purely for fun and releasing caught fish is a much more modern development. The evolution of sport fishing to big game fishing was made possible by the motorized boats. The invention of big game fishing is largely attributed to Dr. Charles Fredrick Holder, who in 1989 published several articles and books on the subject.

King Somesvara's (1127 AD) has mentioned about angling (Matsyavinoda) in his treatise "Manasollosa" in India about recreational fisheries (Hora, 1951). Mahseer (Tor spp) were first described in the Ganges in the early 19th century (Hamilton, 1822) and attained popularity as an angling species through the efforts of the Oriental Sporting Magazine (Nautiyal, 2014). H. S. Thomas has pointed out angling in 1873 (Tank Angling in India), and 1897 (The Rod in India). Edward James "Jim" Corbett (18751955) dealt with mahseer in many of his works besides dealing with tigers and leopards in India. The Angler in India on the Mighty Mahseer authored by Dhu (1923) and Circumventing the Mahseer and Other Sporting Fishes by A. St. J. Macdonald (1948) are worth mentioning in this regard (Sehgal, 1987). British anglers have introduced first time brown trout (1860s) and rainbow trout (1909) in streams and rivers of the Himalayas and Western Ghats (Sehgal, 1999a, b).

Although recreational angling struggled to maintain its popularity after India's 
independence, interests of both foreign and Indian anglers began to focus on Indian freshwater systems and its fish species in the 1970s. Established and emerging angling organizations across the country invested both time and money to build on the earlier foundations of sport fishing (Gupta et al., 2015a). The All India Game Fishing Association acting as a pivotal role in popularizing sport fishing in India with its state and regional representatives. It is a non-profit making, charitable organization with its regional affiliates like Mustad, Maharashtra State Angling Association (MSAA)-Powai (Maharashtra), SHIMANO, The Rogue Angler, Anglers Association (Futala Lake)-Nagpur (Maharashtra), Gypsy's Camp-Bhakhra (Himachal) and Dasvino Town \& Country Club.

\section{Sport fishing sites in India}

The major sites of recreational fishing in India centered round the following places:

- Kashmir- with its network of rivers, streams and high altitude lakes, all abounding in trout, both brown and rainbow, has been rightly defined as an 'angler's paradise'. Major points of angling in the state are the Indus and Lidder rivers, their tributaries and a network of smaller rivers and streams. The best time for fishing here are early mornings and late evenings. There is an, 'ideal' fishing permit that allows you to fish exclusively, in a beat of $2 \mathrm{~km}$.

- Himachal Pradesh - Streams feeding the Beas River in the Kullu Manali region are well known for Brown Trout. The cold mountain streams are well suited for trout, and are home to some of the biggest varieties of Trout. The best beats are at Larji valley, situated on the confluence of the river Larji and Tirthan. Sainj, which is also a trout stream, flows on the other side.

- Uttar Pradesh - Dodital Lake nestled among the snow-clad peaks in the Uttarkashi Himalayas is a fresh water lake and a tempting trout pool, where you can get a good catch, during all seasons. The forest rest house at Dodital and Barkot are ideal for the night stay. Other options for fishing Mahseer in Uttar Pradesh are in the Ramganga and the Sharda rivers in the range of Jim Corbett National Park. You can also go to Rishikesh that offers good fishing sites.

- South India - The best season to go trout-fishing in the southern India is from April to September. Accommodation is available at the forests bungalows. One can even go camping, if the idea is to have some added adventure. Cauvery Fishing Lodge near Mysore is a great place to catch Mahseer. In Kerala streams around the hill stations of Munnar are ideal for sport fishing.

However, more specifically the major angling sites in India are presented in Table 1. 
Table 1. Important angling sites in India

\begin{tabular}{|c|c|c|}
\hline State & Location & Sport Fish \\
\hline Uttarakhand & Ramganga River & $\begin{array}{l}\text { Golden Mahseer, } \\
\text { Goonch catfish }\end{array}$ \\
\hline Himachal Pradesh & Sangla Valley & trout \\
\hline Kashmir & Gulmarg & brown trout \\
\hline Karnataka & Kaveri River & Mahseer \\
\hline Andamans & - & Marine sport fish \\
\hline \multicolumn{3}{|l|}{ Lakshadweep } \\
\hline \multicolumn{3}{|l|}{ Islands } \\
\hline \multirow[t]{3}{*}{ Uttarakhand } & Beas Gha & Golden Mahseert \\
\hline & Pancheshwar Mahakali & \\
\hline & Saryu rivers & \\
\hline \multirow[t]{5}{*}{ Uttarakhand } & Dakpatthar & $\begin{array}{l}\text { Red-finned and yellow- } \\
\text { finned Mahseer }\end{array}$ \\
\hline & River Yamuna & Indian trout \\
\hline & & Goonch catfish Mahseer \\
\hline & Tributaries of the Yamuna & Brown trout, in upper \\
\hline & River Tons and Pabbar & reaches \\
\hline North Sikkim & Teesta & - \\
\hline Meghalaya & Ranikhor & $\begin{array}{l}\text { Golden Mahseer, } \\
\text { Goonch catfish }\end{array}$ \\
\hline Assam & $\begin{array}{l}\text { Jia Bhoroli adjacent to } \\
\text { Nameri National Park }\end{array}$ & $\begin{array}{l}\text { Golden Mahseer, Goonch catfish, } \\
\text { Indian trout }\end{array}$ \\
\hline Arunachal Pradesh & $\begin{array}{l}\text { Brahmaputra and its } \\
\text { tributaries Tezu } \\
\text { on the LohitTipi and } \\
\text { Bhalukpong on the } \\
\text { Bhoroli Pasighat, on the Siang }\end{array}$ & - \\
\hline
\end{tabular}

Developmental phages of sport fishing in India

Earlier development: Wildlife Association of South India (WASI) has taken a $22 \mathrm{~km}$ stretch of the Cauvery River in Karnataka through lease in 1976 to protect the mahseer from anthropogenic threats also, the stocking of mahseer fingerlings, catch and release angling using rod and line was permitted for both domestic and international anglers (Gupta et al., 2015a). Local fishing guidelines were generally followed by the anglers for sustainability. In 1978, a collaborative venture was taken 
by the Indian Tourism Development Corporation (ITDC) with Air India and WASI by organizing an event with the Trans World Fishing Expedition (TWFE) and Boote Mission to get important information about mahseer (Sehgal, 1999b). After that, the National Commission on Agriculture recommended a comprehensive survey of mahseers in the Indian water bodies.

Coorg Wildlife Society (CWS) began protecting mahseer primarily on a $28 \mathrm{~km}$ stretch of the Cauvery River in 1993 (Sehgal, 1999b) which increased to $92 \mathrm{~km}$ in 2006 (Dinesh et al., 2010). The Department of Fisheries, Karnataka, set up a mahseer hatchery during 1987 to produce fingerlings for ranching in rivers and reservoirs in the Western Ghats (Sehgal, 1999b). In 2004, a group of local stakeholders from the Mahseer Conservancy secured a lease from the Forest Department for a $24 \mathrm{~km}$ stretch of the Ramganga River encompassed within the boundaries of Corbett National Park in the State of Uttarakhand (Mahseer Conservancy, 2014). Jeremy Wade, a world renowned recreational angler, helped to promote the mahseer and the goonch catfish (Bagarius bagarius) in his television series "Jungle Hooks India" and "River Monsters" (Gupta et al., 2015a). In northern India, special bylaws of the Indian Fisheries Act permitted capturing of brown and rainbow trout in the Himalayan region with rod and line using artificial and live baits within the regulated fishing season, bag limits, and prescribed baits.
Recent development: Through Indian Wildlife Protection Act (WPA), a legal notice was issued to Karnataka Forest Department for temporary construction of the privately owned Bush Betta fishing camp within the Cauvery Wildlife Sanctuary (Pinder and Raghavan, 2013) as it helped to draw the attention to the potential violation of the WPA by permitting angling within the boundaries of the Cauvery Wildlife Sanctuary. However in due course, the Union Ministry of Environment and Forest (MoEF) has stopped angling within the Cauvery Wildlife Sanctuary. In July 2012, recreational angling was prohibited in all protected areas (PAs) of the country as per the directives of the Apex Court of India. As of now, recreational angling is permitted only on river reaches outside PAs where recreational anglers can go for game fishing. Gupta et al. (2015a) documented a number of species which is usually targeted by the anglers in India which include Tor sp., T. putitora, T. khudree, Neolissochilus hexagonolepis and Gibelion catla. Occasionally caught other Indian native fish species include Channa diplogramma, $C$. marulius, C. punctata, C. striata, Wallago attu, Hemibagrus maydelli, Bagarius bagarius, Labeo rohita, Cirrhinus cirrhosus, Hypophthalmichthys molitrix, Cyprinus carpio, Ctenopharyngodon idella and Aristichthys nobilis.

In northern India, State fisheries departments continuously monitor recreational fishing by providing rod 
licenses on a daily basis. Sport fishing in marine waters has also evolved as a popular recreational activity in the Indian Ocean, the Bay of Bengal and in the lagoons and seas around the Andaman Islands. In marine fishing, vessels have to obtain licenses from the respective State Fisheries Departments. On an average, more than 100 boats operate per month in the marine waters during the peak angling season extending from October to April. Likewise documentation of fresh water game fishes, Gupta et al. (2015a) documented important marine species for sporting and gaming as Caranx ignobilis, Cynoglossus macrostomus, Gymnosarda unicolor, Lates calcarifer, Sphyraena sp., Rachycentron canadum and Thunnus obesus.

Based on the Marine Fisheries (Regulation and Management) Bill, 2012, guidelines and regulatory measures have been formulated by the Department of Fisheries, Govt. of Andaman and Nicobar Islands particularly focusing towards vessel fishing of marine sport fishes. A uniform regulation of 61 day monsoon fishing ban upto $31^{\text {st }}$ July including sport fishing has been imposed during 201718 throughout the Western maritime states viz. Kerala, Karnataka, Goa, Maharashtra and Gujarat.

\section{Major threats to sport fisheries and its management}

For both freshwater and marine water sport fishes the rules and regulations of sport fishing are mainly based on Indian Fisheries Act, 1897. However, some rules and regulations have also been formulated by local level anglers associations for safeguarding their interests and ecological concerns. Sehgal (1987) documented important issues as major constraints for management and conservation of sport fishes. These are poaching, unlawful fishing, competitions among sport fishers and local stakeholders, impact of river basin projects on fish habitat, flow of industrial, domestic and pesticide wastes. Domestic waste water discharge in Dal and Wular Lake in Kashmir, Naini Tal Lake in Kumanon are well known which has a direct bearing upon the native aquatic fauna including the sport fishes. Moreover, the Ganga river system including her tributaries and distributaries viz. the Yamuna, the Sone, the Gomoti are affected by industrial wastes and pollutants as heavy fish mortalities during 1980 near Allahabad was recorded (Sehgal, 1987). Run-off water mixed with pesticide viz. DDT, aldrin, BHC, malathion, parathion from livestock and agriculture field adversely affects the riverine fisheries in India. Such happenings are not uncommon in marine fisheries as in 2017; there was high fish mortality along the Mumbai coast of the Arabian Sea primarily because of oil spills.

Management measures in recreational fisheries are primarily focused on stock enhancement, increase in heterogeneity through species introductions, habitat improvements, elimination of pest species, control of piscivorous avian and fish predators. Fisheries regulations are 
formulated and imposed primarily to regulate fishing effort particularly during closed seasons and closed areas; catch limits, gear restrictions and size restrictions on harvest. However, recreational fisheries are constrained by conflicts with commercial fisheries, other water-based recreational users, water resource development programmes, ecological alterations and water quality degradation. Cowx (2000) opined that if the status of recreational fisheries is to be sustained, more appropriate techniques are developed to provide sound economic valuation of the fisheries and an integrated approach to aquatic resource management is promoted.

\section{Issues in recreational angling sector in India}

Despite the potential benefits of recreational fisheries in India, there are various issues that need urgent attention as they could be constraining the sustainable development of this sector (Gupta et al., 2015a). The fisheries managers and anglers have to be concerned about various issues towards conservation of endangered fish species and to maintain the natural biotic system for sustainable development. Though, several studies are available on the natural history of some mahseers (Nautiyal, 2014), the ambiguities contiguous species taxonomy and distribution make these of little value for practical conservation planning and action. The condition is related for the goonch, Bagarius bagarius, one of the largest freshwater catfish occurring in the Indian subcontinent.
Therefore, recreational fisheries could play a significant role in sustaining research on such freshwater species which are demonstrated through a recent study using angler catch data to generate biological information for conservation and management of mahseers in the Cauvery (Gupta et al., 2015a). Lack of scientific knowledge and co-ordination among government and anglers association/ fishing communities are the major causes of the absence of a uniform strong regulatory measure for holistic management of sport and game fishing of the country.

Lack of perception about biotic responses: No studies have been conducted on post-capture mortalities in mahseer or other species targeted by anglers in India, but studies have implicited that high mortality will be due to exhaustion, injuries, and associated infections (Dinesh et al., 2010) and also due to use of different types of fishing rods (Rocklin et al., 2014). Natural, worm-baited and live baits have been shown to increase the higher mortality rates than use of artificial lures and flies among fish species due to deeper hooking (Wilde et al., 2000). Also, use of circle hooks helps to decrease angling mortality among fish species in that they promote shallow hooking (Cooke and Suski, 2004). Barbless hooks tend to reduce the handling time required to remove the hook (Schaeffer, 2002) and lessen the tissue damage to fish species (Casselman, 2005).

Need for best management practice for sustainable angling promotion: Presently, 
there are no official guidelines specifically focused towards recreational fisheries in India. In June 2014 an "All India Fresh Water Angling Competition" organized by AIGFA in partnership with Maharashtra State Angling Association and WASI in River Cauvery was organized where over 30 skilled recreational anglers participated. A set of nine recreational angling guidelines was provided to each of the anglers as a precondition to participate and stay in the competition. However, such practices are neither advocated nor used by many angling associations. Growing awareness through angler education and cheering fulfillment through enforcement by a legal entertaining angling body is extremely required (Gupta et al., 2015a).

Gupta et al. (2016) envisaged that as the anglers targeting multiple fishing locations throughout India, there is a need for consistent governance structures and policy instruments to support the development of sustainable recreational fisheries while minimizing conflict with other stakeholder groups and also the impacts of catch and release $(C \& R)$ fisheries interactions on individuals and populations (especially for threatened species) need to be studied in the Indian context. Direct participation by recreational anglers in $C \& R$ research could strengthen broader conservation and management initiatives throughout the country by increasing stewardship (Gupta et al., 2016).

Unregulated stocking and introductions The development of recreational fisheries in India has been guided by stocking and introduction of both exotic species and captive bred populations of native species. Many upland lakes and upper reaches of rivers were regularly stocked with exotic salmonids to develop recreational fishing opportunities during the British Raj (Sehgal, 1999a). Similar stocking programs have been carried out in the Nilgiri, Anamalai and Cardamom hills of the Western Ghats (Sehgal, 1999b), with trout hatcheries set up in Avalanche (Nilgiris) and EravikulamRajamalai (Munnar, Kerala). Now a day, recreational trout fishing is commercially encouraged by the local angling associations for self-sustaining populations of the exotic species and their continuous stocking from the local hatcheries.

A specific need to assess in detail the preferences and awareness among $\mathrm{C} \& \mathrm{R}$ anglers regarding the targeting of native and non-native fishes, to understand the extent to which anglers target non-native fish species (Nguyen et al., 2013), and to estimate support for stocking to enhance recreational fishing (Granek et al., 2008). Large-scale stock replenishment of various "species" of mahseer has been carried out in the Western Ghats region, particularly in the Cauvery River (Ogale, 2002), which has resulted in the proliferation of hybrids and the suspected decline of native lineages (Pinder et al., 2015).

Concern about biodiversity hotspots: The most popular fishing locations are mainly situated in the Himalayas and Western Ghats, two of the important biodiversity 
hotspots which are also currently threatened by numerous anthropogenic pressures (Dahanukar et al., 2011). Due to angling, some species have shown a dilapidated population trend and are listed as threatened in the IUCN Red List (e.g., T. khudree and T. putitora assessed as "Endangered"; the goonch catfish, B. bagarius assessed as "Near Threatened" and Cirrhinus cirrhosus assessed as "Vulnerable"), no one of these assessments list recreational angling as a threat to the species (Gupta et al., 2015a).

Poor interference of governance authorities : Raghavan et al. (2012) opined that multi-jurisdictional nature of fisheries governance in India has slowed down the development of recreational fisheries sector. Majority of angling associations in India are registered and catalogue the practice of recreational angling through paid permits, however, a number of unlicensed angling associations continue to operate in major angling locations of India (Gupta et al., 2015a). Communicational lapse among the sport fisheries management associations and government agencies is an additional impediment to the sustainable development of recreational fisheries sector in India. Even if recreational angling tourism provides social and economic benefits to some local communities (Pinder and Raghavan, 2013), there is prevailing low transparency during profit-sharing stages of local stakeholders in India. Moreover, preventing the artisanal fishers from capturing food fish from water bodies protected by angling associations resulted in conflicts in recreation angling areas.

Requirement of scientific adaptive measures: A general lack of evaluation is presently the major concern about the condition of recreational fisheries in India. Few registered angling associations have maintained a record of effort, catch, harvest, and release rates of fish species but they are not maintaining any record on fishing behaviors and information during angling seasons (Gupta et al., 2015a). Additionally, no scientific studies have been conducted to understand the impacts of recreational fisheries on fish population structure or evaluate impacts of recreational fishing activity. An adaptive management approach is necessary from the experiences of the stakeholders so as to build on management successes (FAO, 2012). Setting up of freshwater fish safe zones on river reaches monitored by local communities could be an ideal solution (Gupta et al., 2014a). The suggestion to Legislative support (central or state level) for recreational angling could provide an overall structure to this leisure activity and highlight its associated benefits (FAO, 2012).

Sport fishing should be promoted by male and female members of fishing community. The recreational fisheries sector in India is also dependent on the assistance and support from local communities living near the angling locations, thus recreational fisheries associations would do well to incorporate village communities in their planning for the long-term success of their organizations (Gupta et al., 2014b). Also 
Govt. should initiate the river ranching facilities for more diversification of fish species to maintain the genetic viability.

\section{Eco-tourism and sport fishing}

Eco-tourism contributes to environmental conservation by providing socio-economic benefits through the non-consumptive uses and indirect values of the natural biological resources. Fishery based eco-tourism is an emerging potential area for employment generation and recreational fishing. Among the Himalayan streams and river, Beas and its tributaries and the river Giri (Himalchal Pradresh), Yamuna between Tajwala (Hariyana) to Dhak Pathar, Ganga between Rishikesh to Tehri, river Chenab and its tributaries and river Jia-bhorelu, Dibang, Subarnasiri and Manas (NEH region) are important fishing sites. Presently a few enthusiastic farmers in Kullu-Manali (HP) and in Sikkim have developed their trout farms near highways or tourist places as a sport fishery enterprises. In Pithoragarh district of Uttarakhand has also developed an excellent exotic carp based sport fishery enterprise with integration of boating and swimming facilities. There are also further scope to enhance the income through additional aqua sports and adventuring sports.

The biggest advantage in India is that all the major rivers are sited in easily reachable places and near major cities. Some major rivers and its tributaries where fishing can be enjoyed are Mahanadi, Yamuna, Kaveri, Ganga, Brahmaputra, Sutlej and Teseta. A wide variety of fishes like Golden Mahseer,
Silver Mahseer, Silver Gray Mahseer, Black Mahseer, Trout, Rohu, Katli, Brown Trout are found in these rivers. The coastal waters also have some amazing variety of fishes like Sea Bass, Mackerel, Marlin etc. Keeping in mind the potential of fishing in promoting tourism and adventure sports, the fishing departments of different states have started hatcheries and fish sanctuaries. Fishing license is a major issue for promoting angling tourism. Also most of the trout and mahseer farms are not well connected by roads. Therefore, institutional support and co-ordination is the utmost need to augment sport-tourism in India.

\section{Conclusion}

The sport fisheries in India are confined only to certain regions and the development pattern is not uniform. As sport fishing sector is still in its infancy in India with enough scope and possibilities, various issues comes in the way as attributes likely river ranching, genetic viability and stability, fish diversification, species conservation, awareness among the stakeholders etc. Also sport or recreational fishing has a great influence on the local fishing community as it helps to generate employment opportunity through ecotourism business activities and creation of social capital. Besides, there is enough scope of documentation of indigenous traditional and technical knowledge particularly in designing gears, formulations of baits etc. as the country is extremely rich with such knowledge with diverse topology and habitats. However, the stakeholders must be 
aware of the fall-outs of overall anthropogenic activities in the fishing ground to sustain the environment and biodiversity as a whole. Therefore, co-

\section{REFERENCE}

Allison EH and Ellis F, 2001. The livelihoods approach and management of smallscale fisheries. Marine Policy, 25: 377 388

Arlinghaus R and Cooke SJ, 2009. Recreational fisheries: Socioeconomic importance, conservation issues and management challenges, In: Recreational Hunting, Conservation and Rural Livelihoods: Science and Practice (Dickson B, Hutt J and Adams WM, eds.). (Oxford, UK), Blackwell , pp 39-58

Arlinghaus R, 2006. Overcoming human obstacles to conservation of recreational fishery resources, with emphasis on central Europe. Enviro Conser J, 33: 4659

Barnett A, Abrantes KG, Baker R, Diedrich AS and Farr M et al., 2015. Sport fisheries, conservation and sustainable livelihoods: a multidisciplinary guide to developing best practice. Fish Fish, 17: 696-713. http://dx.doi.org/10.1111/ faf. 12140

Bohensky EL, Butler JRA and Mitchell D, 2011. Scenarios for knowledge integration: exploring ecotourism futures in Milne Bay, Papua New Guinea. J Mar Biol, 11. http://dx.doi.org/10.1155/ 2011/504651 operation and co-ordination among the stakeholders will be a best approach for development and promotion of sport fisheries in various states in India.

Bower SD, Nguyen VM, Danylchuk AJ, Beard Jr TD and Cooke SJ, 2014. Inter-sectoral conflict and recreational fisheries of the developing world: Opportunities and challenges for co-operation. In: Enhancing Stewardship in Small-Scale Fisheries: Practices and Perspectives (McConney P, Medeiros R and Pena M, eds.). Barbados: Too Big To Ignore (TBTI) and Centre for Resource Management and Environmental Studies, The University of the West Indies, Cave Hill Campus. CERMES Technical Report No. 73, pp 88-97

Casselman SJ, 2005. Catch-and-Release Angling: A Review with Guidelines for Proper Fish Handling Practices. Peterborough, Ontario: Fish \& Wildlife Branch, Ontario Ministry of Natural Resources, pp 26

Cinner JE and Orjan B, 2010. Livelihood diversification in tropical coastal communities: a network-based approach to analyzing livelihood landscapes. Plos One. 5:e11999, http://dx.doi.org/ 10.1371/journal.pone.0011999

Cooke SJ and Suski CD, 2004. Are circle hooks an effective tool for conserving marine and freshwater recreational catch-andrelease fisheries? Aquat Conserv Mar 
Freshw. Ecosyst, 14: 299-326

Cowx IG, 2000. Recreational sport fishing in fresh waters. Fisheries and Aquaculture - Vol. III. Encyclopedia of Life Support Systems (EOLSS). ISBN: 978-1-84826560-8, pp 470

Cowx IG, Arlinghaus R and Cooke SJ, 2010. Harmonizing recreational fisheries and conservation objectives for aquatic biodiversity in inland waters. J Fish Biol, 76: 2194-2215

Dahanukar N, Raghavan R, Ali A, Abraham R and Shaji CP, 2011. The status and distribution of freshwater fishes of the Western Ghats, pp 116. In: The Status and Distribution of Freshwater Biodiversity in the Western Ghats, India. (Molur S, Smith KG, Daniel BA and Darwall WRT, eds). (Cambridge/ Coimbatore), IUCN/Zoo Outreach Organization, pp 21-48

Danylchuk AJ and Cooke SJ, 2011. Engaging the recreational angling community to implement and manage aquatic protected areas. Conser Biol, 25: 458-464

Dhu S, 1923. The angler in India or the mighty Mahseer: Being the Incorporated 3rd Edition of The Angler in Northern India and the Mighty Mahseer [With Plates], Allahabad

Dinesh K, Nandeesha MC, Nautiyal P and Aiyappa P, 2010. Mahseers in India: A review with focus on conservation and management. Indian J Anim Sci, 80: 2638

Everard M and Kataria G, 2011. Recreational angling markets to advance the conservation of a reach of the Western Ramganga River, India. Aquat ConserMar Freshwater Ecosyst, 21: 101-108

FAO, 2012. Recreational Fisheries. FAO Technical Guidelines for Responsible Fisheries, No. 13. (Rome), FAO, pp 176

Granek EF, Madin EMP, Brown MA, Figueira $\mathrm{W}$ and Cameron DS et al., 2008. Engaging recreational fishers in management and conservation: Global case studies. Conserv Biol, 22: 11251134

Gupta N, Bower SD, Cooke SJ, Danylchuk AJ and Raghavan R, 2016. Practices and attitudes of Indian catch -and-release anglers: identifying opportunities for advancing the management of recreational fisheries. J Threat Taxa, 8(4): 8659-8665; http://dx.doi.org/10.11609/ jott.2410.8.4.8659-8665

Gupta N, Bower SD, Raghavan R, Danylchuk AJ and Cooke SJ, 2015a. Status of recreational fisheries in India: Development, issues, and opportunities. Reviews Fish Sci Aquacul, 23 (3): 291301. DOI: 10.1080/23308249. 2015. 1052366

Gupta N, Raghavan R, Sivakumar K, Mathur VB and Pinder AC, 2015b. Assessing recreational fisheries in an emerging economy: Knowledge, perceptions and attitudes of catch-and-release anglers in India. Fish Res, 165: 79-84

Gupta N, Raghavan R, Sivakumar K and Mathur VB, 2014a. Freshwater fish safe zones (FFSZs): A prospective 
conservation strategy for river ecosystem in India. Curr Sci, 107: 949-950

Gupta N, Sivakumar K, Mathur VB and Chadwick MA, 2014b. The "tiger of Indian rivers": Stakeholders' perspectives on the golden mahseer as a flagship fish species. Area, 46: 389-397

Hamilton F, 1822. An Account of the Fishes Found in the River Ganges and Its Branches. Edinburgh: Hurst, Robinson, and $\mathrm{Co}$, pp 405

Holland SM, Ditton RB and Graefe AR, 2009. An ecotourism perspective on billfish fisheries. J Sustain Tour, 6: 97-116

Hora SL, 1951. Knowledge of the ancient hindus concerning fish and fisheries of India. J Asiat Soc Lett, 17: 145-169

International Game Fish Association (IGFA), 2016. IFGA Fish Database. Florida (USA), (http://igfa.org/fish/fishdatabase.aspx)

Lewin WC, Arlinghaus R and Mehner T, 2006. Documented and potential biological impacts of recreational fishing: Insights for management and conservation. Rev Fish Sci, 14: 305-367

MacDonald A St J, 1948. Circumventing the Mahseer and other sporting fish in India and Burma. (MacDonald A St J, edn.), Bombay: Natural History Society, pp 360

Mahseer Conservancy, 2014. <www. mahseerconservancy.com $>$ accessed 12th September 2014
McCully CB, 2000. The Language of FlyFishing Taylor \& Francis, ISBN 978-157958-275-3, pp 76-78

Nautiyal P, 2014. A review on the art and science of the Indian mahseers (gamefish) in the 19th-20th century - road to extinction or conservation? Proc Natl Acad Sci India Sect B Biol Sci, 84: 215236

Nguyen VM, Rudd MA, Hinch SG and Cooke SJ, 2013. Recreational anglers' attitudes, beliefs, and behaviors related to catch and-release practices of Pacific salmon in British Columbia. J Environ Manage, 128: 852865

Ogale SN, 2002. Mahseer breeding and conservation and possibilities of commercial culture. The Indian experience. In: Cold Water Fisheries in the Trans-Himalayan Countries (Petr T and Swar DB edn., Rome), FAO, FAO Fisheries Technical Paper 431, pp 376

Pereira JM, Petrere-Jr M and Ribeiro-Filho RA, 2008. Angling sport fishing in LoboBroa reservoir (Itirapina, SP, Brazil). Brazilian J Biol, 68: 721-731

Pinder AC and Raghavan R, 2013. Conserving the endangered Mahseers (Tor spp.) of India: The positive role of recreational fisheries. Curr Sci, 104: 1472-1475

Pinder AC, Raghavan R and Britton R, 2015. The legendary humpbacked mahseer Tor sp. of India's River Cauvery: An endemic fish swimming towards extinction. Endang Species Res, 28: 11-17

Pomeroy RS, Ratner BD, Hall SJ and 
Pimoljinda J, 2006. Coping with disaster: rehabilitating coastal livelihoods and communities. Mar Policy, 30: 78693

Raghavan R, Ali A, Dahanukar N and Rosser A, 2012. Is the Deccan mahseer, Tor khudree (Sykes 1839) (Pisces: Cyprinidae) fishery in the Western Ghats Hotspot sustainable? A participatory approach to stock assesment. Fish Res, 110: $29-38$

Rocklin D, Levrel H, Drogou M, Herfaut J and Gerard V, 2014. Combining telephone surveys and fishing catches self-report: The French sea bass recreational fishery assessment. PLoS One, 9: e87271

Schaeffer JS, 2002. Performance of barbed and barbless hooks in a marine recreational fishery. North Am J Fish Manag, 22: 229235

Sehgal KL, 1987. Sport fisheries of India. Indian Council of Agricultural Research. New Delhi. pp 126

Sehgal KL, 1999a. Coldwater fish and fisheries in the Indian Himalayas: Rivers and streams. In: Fish and Fisheries at Higher Altitudes: Asia. (Rome), FAO, Fisheries Technical Paper, no. 385, pp 304

Sehgal KL, 1999b. Coldwater fish and fisheries in the Western Ghats, India. In: Fish and Fisheries at Higher Altitudes: Asia (Rome), FAO. Fisheries Technical Paper, no. 385 , pp 304

Singh AK, 2015. Advances in Indian coldwater fisheries and aquaculture. J Fisheries Sciences.com, 9(3): 048-054
Singh AK, Kumar P and Ali S, 2014. Ichthyofaunal Diversity of the Ganges River System in Central Himalayas, India: Conservation Status and Priorities. In: Rivers for Life Proceedings of the International Symposium on River Biodiversity: Ganges-Brahmaputra-Meghna River System, Ecosystems for Life, A Bangladesh-India Initiative (Sinha RK and Ahmed B eds). IUCN, International Union for Conservation of Nature, pp 208-214, ISBN:978-93-5196-807-8

Suski CD and Cooke SJ, 2007. Conservation of aquatic resources through the use of freshwater protected areas: opportunities and challenges. Biodivers Conserv, 16: 2015-2029

Whitelaw W, 2003. Recreational billfish catches and game fishing facilities of Pacific Island nations in the Western and Central Pacific Ocean. Mar Freshwater Res, 54: 463-471

Whitelaw W, 2013. Country guide to game fishing in the Western and Central Pacific. Noumea (New Caledonia): Secretariat of the Pacific Community; (http://www.spc.int/ DigitalLibrary/ $\mathrm{D}$ o c / F A M E / M a n u l s / Whitelaw_2001_Countryguide_ Gamefishing. pdf)

Wilde GR, Muoneke MI, Bettoli PW, Nelson KL and Hysmith BT, 2000. Bait and temperature effects on striped bass hooking mortality in freshwater. North Am J Fish Manag, 20: 810-815

Article received on 10.04.2018 and accepted for publication on 08.05.2018 